\title{
A Study of Land Degradation Pattern in the Mahin Mud-beach Coast of Southwest Nigeria with Spatial-statistical Modelling Geostatistics
}

\author{
Mayowa Fasona (Corresponding author) \\ Department of Geography, University of Lagos, Akoka 101017, Lagos, Nigeria \\ Tel: 234-802-312-7998 E-mail:mfasona@unilag.edu.ng; mfasona@yahoo.com \\ Ademola Omojola \& Alabi Soneye \\ Department of Geography, University of Lagos, Akoka 101017, Lagos, Nigeria \\ E mail: aomojola@unilag.edu.ng; asoneye@unilag.edu.ng
}

Received: September 9, 2010 Accepted: September 17, 2010 doi:10.5539/jgg.v3n1p141

\begin{abstract}
This study utilized remote sensing and spatial-statistical geostatistics to model future land degradation in the mud-beach coast of southwest Nigeria. Current landcover was derived from Landsat $\mathrm{ETM}^{+}$data. Model input data consists of 12 predictor variables. Attribution of weights to variables was done through multi-criteria evaluation. These weights were used to develop logistic regression function for simulating probability surface maps. Degraded lands accounted for about $30.2 \%$ of the total landcover with permanently inundated lands and bare surfaces contributing $22.4 \%$. The results suggest soil, geology, elevation, distance to ocean, and location of old bitumen wells as the most important predictor variables. Simulated composite probabilities for transiting into degraded lands range between 0.4184 and 0.4871 in the next 20 years (from 2001) to between 0.4284 and 0.4973 in the next 100 years. Mangrove, scrub/coastal grassland, farmland/fallow and built-up areas appear to have higher probabilities, while the palm swamp ecosystems have the least.
\end{abstract}

Keywords: Landcover, Land degradation, Spatial-statistics, Probability surface, Mud-beach coast

\section{Introduction}

Disruption and degradation of terrestrial ecosystems present fundamental natural resource challenges to environmental scientists, analysts, managers and planners. Land degradation, as an integral part of terrestrial environmental changes (Riebsame et al., 1994), represents a decline in the usable natural resource base (Lambin, 1997; Mitchell, 1989). It also signifies a reduction in the capacity of land to produce desirable biomass (Zurayk et al., 2001). It impairs ecosystem functions and services (http://www.maweb.org/documents/document.299.aspx.pdf), and presents potential threats to people, livelihood and make them vulnerable to other hazards (Verstappen, 1999; PRB, 2001; UNEP/GRID-Arendal, 2005). Land degradation is a strong factor in changes in terrestrial ecosystems brought by human activity (Ojima et al., 1994). It diminishes the resilience and ability of ecosystems to absorb perturbations (Fasona and Omojola, 2009). In recent times, studies have also suggested that increasing degradation of land ecosystems has serious impact on climate with a general tendency for rainfall and evaporation to decrease (Taylor et al., 2002; Abiodun et al., 2008; German Advisory Council on Climate Change, 2008; Wang and Eltahir, 2000; MacKellar et al., 2009; Fuller and Ottke, 2002; Hoffmann and Jackson, 2000). A degraded land that is perpetually exposed to climate and human induced forces is susceptible to declining ecosystems function including production and self-regeneration unless consciously redirected.

Biophysical degradation of land may be caused by a range of factors including natural forces and human-induced disturbances such as prolonged use or mismanagement of land (Veldkamp and Fresco, 1996; Feng et al., 2009). Except where occasioned by spontaneous natural or human action, land degradation is a creeping disaster. It often begins as isolated patches scattered across an area and progresses in discontinuous fashion. If not addressed on time, it expands and combines and before long a large area is affected. This progressive slow-steady process 
creates a fallacious impression of security (German Advisory Council on Climate Change, 2000). Although land degradation can be clearly contextual (Warren, 2002; Reynolds et al., 2003) making different actors to perceive different things, it becomes an undeniable hazard when it directly or indirectly impacts the existence and livelihood of some population (Dormany, 2000).

\section{Background}

The progressive slow-steady spread of land degradation tends to make its actual observation, impacts measurement, and determination of the quantity of land at risk very complicated (Feddema and Freire 2001). Integrating remote sensing (RS), geographic information systems (GIS) and environmental modelling techniques has, however, become more promising in accomplishing the task of inventory and assessment of ecosystems health and degradation. The traditional in-situ field survey is narrow in spatial and temporal scope, inefficient and costly, tedious and time consuming and difficult in large remote locations and difficult terrain. In addition, results obtained from traditional methods of assessment are often unreliable due to the difficulty in mapping contributing factors at a high level of accuracy (Feng et al., 2009). RS and GIS offer tools to perform systematic inventory and diagnostic assessment of land resources, land degradation and ecosystems health over consistent space and time.

The process of landcover change which produces degradation of land ecosystems is driven by some set of proximate and underlying factors (Verburg et al., 2000; Verburg et al., 2002). The proximate drivers may be natural or human activities or immediate actions at local level which may include climate, biophysical attributes, and human activities, among others (Verburg et al., 2002; Verburg et al., 2000; Lebel and Steffen, 1998; Geist and Lambin, 2002; Folke et al., 1998; MEA, 2005). The underlying driving forces, on the other hand, are fundamental social processes. They are exogenous variables (Stéphenne and Lambin, 2001) and diverse considerations including political, economic, demographic and social processes. Although they may be difficult to independently assess or quantify, nevertheless, they drive the proximate factors in most cases. This complex relationship between the proximate and underlying drivers has been expressed in models of landuse change. Generally, the models try to disentangle and determine the rate, pattern and trajectories of landuse change and by extension the propagation of land degradation across space and time.

While the proximate factors may be easy to model, the deeper underlying drivers that control the rates of change operates at a higher level of the hierarchy. However, modeling the operation of both driving forces requires the combination of system, actor-based and narrative approaches through multiple-criteria evaluation (Veldkamp and Lambin, 2001). According to Veldkamp and Lambin (2001), landuse change models are often used to assess the impact of landcover on biophysical processes, e.g. climate variability, land degradation, ecosystem stability and diversity. A vital prerequisite to the development of realistic models of landuse change is the identification of the most important drivers of change, and how best to represent them in a model. The selection of candidate predictor variables thus relies heavily on prevailing theories on driving forces, knowledge of local conditions and data availability and quality (Veldkamp and Verburg, 2004). Landuse change models too are abstractions and approximations which fall short of incorporating all aspects of reality, but provide valuable information on a system's behaviour under a range of conditions. Some elements of subjectivity may therefore be expected in the selection of input variables. As a standard procedure, they equally need to be sieved through to seek out the one that is better suited for understanding the problems at hand (Hagget \& Chorley, 1967; Lambin, 1997; Mazerolle, 2004; Veldkamp and Lambin, 2001).

Spatial-statistical models which are spatially explicit are born from the combination of remote sensing, GIS and multivariate mathematical models with emphasis on spatial distribution of landscape elements and changes on landscape patterns (Lambin, 1997). They satisfy the key tests of spatial explicity including the invariance, representation, formulation and the outcome tests (Berger et al., 2002). This family of models project and display in cartographic form future landscape patterns which would result if the present land management practices continue. For instance, they analyze the location of landcover changes in relations to maps of natural and cultural landscape variables within a GIS. Spatial-statistics models are useful for predicting the location of future changes and vulnerable places to change which help to mitigate negative impacts on specific places and people (Braimoh and Onishi, 2006). GIS is important for developing spatial-statistical models because it provides the foundation for representation and handling of spatially explicit information. It also accepts a wide range of analytic and modeling functions. Spatial-statistical landuse change models offer the possibility to test the sensitivity of landuse patterns to changes in selected variables. In addition, they allow testing of the stability of linked socio-ecological systems through scenario building (Veldkamp and Lambin, 2001). They often use the binary logistic regression which is an example of binary choice models. The use of logistic regression for generating models in landuse change and environmental studies has been predicated on its ability to 
accommodate dichotomous data. It requires no elaborate number of assumptions and also allows for categorical data in the independent variables. It eliminates homoscedacity assumption and normally distributed error terms associated with other multivariate statistics (Mitchell, 2001).

This study tests the applicability of spatially explicit spatial-statistical geostatistics model to simulate ecosystems degradation in a densely settled rural tropical coast. The Mahin mud beach coast of southwest Nigeria (the study area) is already being ravaged by degradation including sea water incursion and decimation of delicate ecosystems, coastline erosion and up-root of communities, and accelerated sedimentation of ponds, lakes and lagoons. The paucity of information on underlying drivers and processes leading to ecosystems degradation and the extent to which livelihood of inhabiting communities have been impacted (Iyun, 1998) makes this study exploratory. Thus, the objectives are to (a) map the coverage of ecosystems degradation (b) determine the important proximate drivers of ecosystems disruption and degradation, and (c) simulate the magnitude of probable future degradation.

\section{Materials and methods}

\subsection{Study area}

The study area is the Mahin transgressive mud-beach coast of southwest Nigeria sandwiched between the Lagos barrier lagoon coast and the arcuate coast of the Niger Delta. It lies approximately between latitudes $5^{0} 45^{\prime} \mathrm{N}$ and $6^{0} 30^{\prime} \mathrm{N}$ and longitudes $4^{0} 30^{\prime} \mathrm{E}$ and $5^{0} 07^{\prime} \mathrm{E}$. It is about $120 \mathrm{~km}$ east of the city of Lagos and covers about $3,300 \mathrm{~km}^{2}$ extending $88 \mathrm{~km}$ along the coastline and between 19 and $50 \mathrm{~km}$ inland from the Atlantic coastline (Fig 1). The general climate is tropical humid condition of the Koppen-Geiger Am classification (Kottek et al., 2006). The mean annual rainfall is about $2,721 \mathrm{~mm}$, mean annual number of rain days around 170 , mean monthly rainfall around $229 \mathrm{~mm}$ and mean annual temperature of about $27.8^{\circ} \mathrm{C}$ (Fasona, 2007).

The mud beach coast evolved from the growth of the Niger delta into the gulf of guinea following gradual retreat of the sea after a short-lived Paleocene transgression (Wright et al., 1985). Major geological formations include general alluvium, lagoonal marshes, abandoned beach ridges and coastal plains sand. The exposures on the general alluvium reveal coarse, clayey, unsorted sands with clay lenses and occasional pebble beds which are lithologically indistinguishable from typical coastal plains sand strata (Jones and Hockey, 1964). These formations produce generally swampy soils on the nearly level coastal plains sand on alluvium, and very deep, well drained soil, with very dark brown to dark brown surface sands from the nearly level coastal plains on coastal plain sand (Federal Department of Agriculture and Land Resources, 1985). Elevation rises from about $1 \mathrm{~m}$ along the coastline to between 35 and $55 \mathrm{~m}$ in the upland (Fasona and Omojola, 2009; Iyun and Oke, 2000). Although the firm upland area in the north is dissected by some seasonal rivers of the western littorals, surface drainage is sparse around the coast.

The original vegetation types consist of heavy forests and creepers, mosaic of forest and raffia complexes, and some red mangrove (rhizopora) around the coast (Akegbejo-Samson, 2008). However, with active forest removal going on in the northern axis and extensive areas of marsh and mangrove forests being decimated in the southern parts, a large stretch of land along the coastline is now permanently inundated. This poses the likely danger of compromising livelihoods and food security for thousands of peasant population in hundreds of rural communities. There is a dearth of literature on the onset, magnitude and major drivers of ecosystems degradation in the mud beach coast. The main degradation processes identified include the emergence of scrub/coastal grassland (an indication of persistent pressure on other ecosystems), permanent inundation of lands (a likely pointer to land subsidence), coastline erosion, canalization, open burrow pits or excavations, and inundation or accelerated sedimentation of small lakes, ponds and lagoons. These became more pronounced around the 1970s when the mud beach coast started experiencing increase in off-shore oil drilling activities (Iyun, 1998; Fasona and Omojola, 2009). Outside the coast of Lagos, the mud beach coast is probably the most densely settled portion of the Nigerian coast with clusters of first-line settlements. Livelihood activities revolve around fishing and farming. The inhabitants of upland settlements are peasant farmers while the coastal communities rely on the inland ponds, lakes and small lagoons for fishing. Some relatively bigger communities also thrive on native gin (locally called 'ogogoro') production from raffia palms that dominate the palm-swamp ecology of the creeks. Lumbering is also an important and lucrative trade as suggested by large number of logs on the creeks waiting to be floated to sawmills in Lagos.

\subsection{Data and data sources}

Spatial datasets utilized include landuse and landcover (LULC) data derived from Landsat $\mathrm{ETM}^{+}$imagery acquired in 2001, geology, soil, elevation, and oil related spatial data including location of oil fields and flow-stations, pipelines, and old bitumen exploratory wells. In addition, locations and names of communities 
were digitized from topographical maps and verified on the field. Table 1 shows the characteristics of these data and the candidate predictor variables generated from each. The scale of the original data sets was emphasized to show the spatial resolution disparity of available data sets in the study area which is typical of most parts of the country.

\subsection{Procedure}

\subsubsection{Image analysis, classification and interpretation}

Standard UTM grid rectified Landsat $7 \mathrm{ETM}^{+}$image bands $(1,4$, and 7$)$ sourced from the freely available USGS Landsat on-line data archive (www.landcover.org) were stacked into true colour composite image for further analysis. The image acquired in dry season (February 2001) provided a good basis to isolate changes due to slow and persistent land degradation from the effects of rapid and spontaneous processes such as rainfall, flooding and tidal action. The USGS Anderson land classification scheme (Anderson et al., 1976) was adopted and modified to generate suitable LULC classes. A heads-up visual classification procedure based on observed spectral, tonal, and colour was employed for extraction of landuse and cover information from the composite imagery. This becomes necessary because the vector product derived from the image interpretation process is required for integration with other vector data layers on Table 1. Identification, delineation and classification of features from the imagery were done at a consistent scale of about 1:50,000 with a minimum mapping unit of $0.5 \mathrm{ha}$. LULC classes interpreted from imageries were validated for accuracy with fieldwork carried out using Garmin76 GPS. A total of 585 points from fairly homogeneous stands were captured and their attributes recorded. The points were downloaded, analyzed, and used for quantitative assessment of attribute accuracy for the image-derived maps (Jensen, 1986). The computed overall map accuracy was $87.4 \%$, with average omission and commission errors of $11.1 \%$ and $9.1 \%$ respectively.

\subsubsection{Selection of predictor variables for land degradation modeling}

Twelve proximate spatial predictor variables (physical and human influence factors) were selected for analysis. The choice of these variables was based on data availability, perceived importance in influencing LULC change and land degradation, and ease of their parameterization. Although this shift from driving forces to proximate causes, for data convenience, might obscure causality (Veldkamp and Lambin, 2001), it is however a good probing start especially in an area where little information is known about the inter-relationships between different processes simultaneously responsible for ecosystems degradation. The variables selected include distance from old bitumen exploratory well (OLDWELL_), distance from road (ROAD_5M), soil type $\left(M A H \_S O L\right)$, distance from known oil field (OILFIELD), geology type (GEOL), distance from known oil flow-stations $(F L S)$, distance from natural drainage (DRAIN_P), distance from dredged canal (DRAIN_LI), elevation (ELEV), distance from the ocean $(O C E A N)$, distance from human settlement $(B U A)$, and normalized difference vegetation index (NDVI86). Elevation was derived from a level II digital elevation model (DEM) created from digitized contours and spot heights from the sets of 1:50,000 topographic maps. Geology data file was derived from the digitized geological map, and soil types from digitized soil map. NDVI was derived by processing bands 3 (R) and 4 (NIR) of the Landsat imagery, while distances from the ocean, human settlements, dredged canals, and roads were generated from the derived LULC map. Oil fields and location of flow-stations were digitized from oil infrastructure base map, while the locations of old bitumen exploratory wells were digitized from the geological map.

\subsubsection{Generation of weights for the criteria}

Multi-criteria analysis based on weight attribution as used in some other geo-environmental researches (see Wheeler 1994) was employed. The predictor variables were ranked, with scores assigned and weights calculated for each variable class (Table 2). Weights were allocated based on their assumed vulnerability and resilience to land transformation and degradation elements. The generation of intra-class weight was straightforward. For elevation, geology and soil, intra class weight was based on perceived susceptibility or resistance of the different sub-classes to land degradation. A more resistant class has lower score than a less resistant or more susceptible class. For the index of greenness, the NDVI was categorized into 10 classes to obtain aggregate categorical values for the pixels.

For other layers including distance from ocean, distance from known oil field, distance from drainage, distance from human settlement, distance from old bitumen well and distance from dredged canal, values were generated by creating concentric buffers at desired intervals around the different features of interest and assigning them values. The values of the buffer zones decrease outward and thereby represent diminishing severity of effects. Each variable layer was converted into raster grids of $30 \mathrm{~m}$, and their cell values recalculated with the aggregate weight of each sub-class. The cell values for all the raster grid layers were digitally written into the polygon 
attribute table (PAT) of the Landsat image-derived LULC map (LU2001.shp) using the spatial collocation principle. An additional Boolean field depicting the presence/absence of degradation for each record in the PAT was added. Figure 2 shows the framework used for developing the probability surface maps.

\subsubsection{Spatial-statistical model development}

Land degradation is viewed as an incremental process, and the relations between land degradation and its driving factors are therefore evaluated using binary logistic regression (Lambin 1997). In this case, logistic regression function is used to indicate the probability for a certain polygon to be degraded given a set of driving factors, as expressed by:

$$
\text { In }[p /(1-p)]=a+b X 1+c X 2
$$

Where: $I n$ is the natural logarithm, $\quad p$ is the probability of an event occurring, $a, b$ and $c$ are coefficients, and $X 1$ and $X 2$ are the independent variables (driving factors).

Rearranging (i):

$$
\mathrm{p}=1 /[1+\exp (-1 *(\mathrm{a}+\mathrm{bX} 1+\mathrm{cX} 2 \ldots \ldots . .))]
$$

With the functional form in (ii), the denominator approaches a value of 1 as the value of $a+b X 1+c X 2 \ldots$ increases and the entire equation approach a ratio 1:1 or high probability. Conversely, as the value of $a+b X 1+c X 2$.. decreases, the exponent term in the denominator increases thereby reducing the overall ratio of the equation. As the exponent term increases more and more, the equation as a whole approaches zero. The PAT for LU2001.shp was transferred into SPSS software, a binary logistic regression analysis was run and the model output parameters (log likelihoods, number of variables, confidence intervals, etc) were inspected. Five models were developed using combinations of different independent (predictor) variables.

\subsection{Model evaluation}

\subsubsection{Check for multi-collinearity}

The check for multi-collinearity is a way of assessing the true independence of variables and check for the presence of redundant and causal-irrelevance predictor variables that has possibility of inflating the standard error of the coefficients. The stepwise process in the regression procedure helps to assess any multi-collinearity problems (Kok and Veldkamp, 2001). No multi-collinearity was detected among the 12 independent variables (covariates) used.

\subsubsection{Test for spatial autocorrelation}

Spatial analysis frequently employs model-based statistical inference, the dependability of which is based upon the correctness of posited assumptions about a model's error term. The assumption of independence of factors is a condition of classical statistical methods. Spatial autocorrelation, a hallmark of geographic data and basis for defining spatial organization, invalidates this assumption (Overmars et al., 2003; Griffith, 1987). Spatial statistics is a set of statistical tools used to exploit spatial autocorrelation contained in georeferenced data usually for spatial prediction purposes. In its simplest form geostatistics is a set of techniques for estimating the local values of properties that vary in space from sample data (Curran and Atkinson, 1998).

Spatial autocorrelation defines how lots of complex systems involving human-environmental interaction and processes of eco-geographic significance propagate across space. Based on this, several works related to the present study have explored the spatial autocorrelation advantage to model processes including urbanization (Braimoh and Onishi, 2006; Fang et al., 2005) and agricultural landuse (Gobin et al., 2002) among others, using spatial-statistical models developed through logistic regression. Some other family of landuse models which employ the cellular automata and Markov principles where landcover changes develop as growth process in areas of high suitability proximate to existing areas (Eastman, 2009; Pontius and Malanson, 2005; Pontius and Schneider, 2001; Hall et al., 1995) also explore the spatial autocorrelation advantage.

However, non-spatial analysts especially view spatial autocorrelation as interference because mean response and standard errors improve when spatial autocorrelation is accounted for (Overmars et al., 2003; Griffith, 1987). Ignoring latent spatial autocorrelation results is, therefore, not advised because it increased uncertainty in model results (Kok and Veldkamp, 2001). It is important when working with georeferenced datasets to compute a spatial autocorrelation index to determine the degree of autocorrelation in the factors (Griffith, 1987; Kok and Veldkamp, 2001; Dale and Fortin, 2002) before deciding the next step.

The Moran's $I$ spatial autocorrelation index was computed for the 12 predictor factors within ArcView 9.2 ${ }^{\circledR}$ software using the inverse distance function. Given a set of features and an associated attribute, it evaluates 
whether the pattern expressed is clustered, dispersed, or random. The tool calculates the Moran's $I$ Index value and a $Z$ score evaluating the significance of the index value and the results are shown on Table 3 . In general, a Moran's Index value near +1.0 indicates clustering while an index value near -1.0 indicates dispersion. The results show that the factors are weakly autocorrelated and we therefore opt to disregard the effect of spatial autocorrelation. (See also Kok and Veldkamp, 2001).

\subsubsection{Akaike Information Criteria (AIC)}

A solid framework for a systematic validation of projections generated from landuse change models is important (Veldkamp and Lambin 2001). Unlike in ordinal least squares (OLS) regression where the coefficient of determination $\left(R^{2}\right)$ gives a measure of model fit, the logistic regression has no such equivalent. More importantly, traditional hypothesis testing which treats observations as either true or false and the human assigned significance values (́) may not be representative of environmental and natural processes (Burnham and Anderson 1998). For this study, the model's goodness of fit was evaluated using the Akaike Information Criteria (AIC) (Burnham and Anderson, 1998; Mazerolle, 2004) which offers an alternative to the traditional hypothesis testing. The AIC evaluates the degree of truth associated with each model (in a suite of potential models) and the best combination (lowest value) of goodness of fit (log likelihood) and complexity (number of parameters) and then selects the one which best approximates the true processes occurring in the observed data. This is represented by:

$$
\mathrm{AIC}=-2 \log \text { like }+2 \mathrm{~K}
$$

Where -2loglike is the goodness of fit or log likelihood of a specific model, and $K$ is the number of parameters estimated for the specific model.

Parameters are the estimated slope coefficients for the model plus the constant term (intercept). Hence, the $K$ value equals the number of independent variables in the model plus 1. Thus AIC can be corrected for sample data using:

$$
\mathrm{AICc}=[\mathrm{AIC}+(2 \mathrm{~K}(\mathrm{~K}+1) /(\mathrm{n}-\mathrm{K}-1)]
$$

Where $A I C c$ is corrected AIC, $K$ is the number of parameters and $\mathrm{n}$ is the sample size.

In a suite of candidate models, the one that yields the smallest deviation when the minimum AICc is subtracted from the others is theoretically assumed to be the best model (Bedrick and Tsai, 1994; Cavanaugh, 1997). Akaike weights (AIC $\{\mathrm{wi}\}$ ) which represents the ratio of $\Delta \mathrm{i}$ values for each model relative to the whole set of all candidate models also provide another measure of the strength of evidence for each model.

\subsection{Probability surface maps}

The coefficient and covariates of the logistic regression equation are provided from the SPSS analysis results. The model equation is transferred to GIS. The vector file LU2001.shp is then converted into a raster grid file. Using the spatial analysis tools within GIS, probability surface maps were simulated from the LU2001 grid file by keying in the model function. Probability maps were simulated for 2001 (to compare with the real map) and for the years 2021, 2031, 2051, and 2101. These maps express the probabilities that a given class will be degraded in the next time period.

\section{Results and discussions}

\subsection{Coverage of degraded lands}

The degraded ecological classes observed from the analysis of the Landsat imagery-derived LULC map of 2001 and their corresponding extents in 1965 and 1986 as reported by Fasona (2007) are presented on Table 4. Degraded lands accounted for about $30.2 \%$ (from $10.5 \%$ in 1986) of the total landcover of the mud beach coast in 2001. Permanently inundated lands and bare surfaces jointly contribute about $22.4 \%$ of degraded ecosystems. Bare surfaces include areas where saline intrusion has occurred, eroded/out washed surfaces, and exposed white (glass) sands which are typically un-productive and devoid of any vegetal cover. A comparison with results for previous decades shows no mappable degraded ecosystem in the 1960s while bare surfaces rose from $1.7 \%$ in 1986 to $12.4 \%$ in 2001 . A popular thinking by the local population is that the saline water inflow and permanent inundation recorded in the mud beach coast are externalities of oil exploration activities (Iyun, 1998). The period 1980s coincided with upsurge in offshore oil exploration and drilling activities and construction of canals to facilitate movement between the creeks and off-shore fields and to route pipelines that connect on-shore oil wells and offshore platforms to flow-stations and tank-farms which are located in the Niger Delta wetlands. These constructions led to decimation of delicate freshwater mangrove and marsh ecosystems through saline water inflow into land areas. 
The summary of the major degradation types, their driving factors and the rate of their propagation, and by implications, the loss of critical natural resource stock are shown on Table 5. The identified drivers of ecosystems degradation include oil prospecting and exploitation activity, agriculture and logging activities, and to a lesser extent, natural coastal processes. The decimation of marsh and mangrove ecosystems, sedimentation and inundation of lakes and small lagoons, loss of livelihood, dislocation of local economies and uprooting of communities experienced in the mud beach coast are pointers to the impacts of active land degradation processes. Some of the socio-ecological dimensions of human-induced land degradation especially on human livelihoods have been discussed in an earlier paper (see Fasona and Omojola, 2009).

\subsection{Predictor variables for ecosystems degradation}

The binary logistic regression of the 12 predictors with the discrete dependent variable was constructed in the statistical package for social sciences (SPSS) using the block entry of variables method which builds the equation by entering all variables (covariates) into the model at once and achieves the equivalent of a simultaneous multiple regression (SPSS for Windows 15.0.0, 2006). The cut value for both step 0 and step 1 iterations is 0.100 , and the overall predicted percentage was $51.6 \%$. The log likelihood (-2LL) for the global model (that utilizes all the 12 variables) is 652.335 , and the Cox \& Snell $R^{2}$ and Nagelkerke $R^{2}$ respectively indicates that $8.4 \%$ and $14 \%$ of the variance in the dependent variable is explained by the covariates. This suggests that the underlying drivers, which in this case should include the influence of oil and gas activity, government policies and demographic changes constitute very strong influence for explaining the rate and pattern of transformation of good lands into degraded lands in the mud beach coast.

In the result for the performance of the predictors (Table 6), the $\beta$ column lists the constant (intercept) and coefficients for the logit equation. The relative contributions of independent variables to landcover transformation into degraded lands are indicated by $\operatorname{Exp}(\beta)$. An odds ratio that is greater than 1 indicates a positive effect, i.e. the odds of land degradation increases with a unit increase in the independent variable by 1 standard unit. On the contrary, an odds ratio that is less than 1 indicates that an increase in the independent variable decreases the odd of land degradation. An odds ratio of 1 suggests that the odd of land degradation is neutral to an increase in the level of independent variable. The results suggest that adding one more unit of distance to old bitumen exploratory well (OLDWELL_) increases the odd of land degradation by a factor of 1.045. In the same way, one more unit will increase the odd of land degradation by 1.002 for soil, 1.003 for geology, 1.027 for elevation and 1.021 for distance from the ocean. On the other hand, and logically too, the odd of land degradation decreases with increase in distance from road, distance away from oil field, distance away from flow-stations, distance away from drainage, distance away from dredge-canal, distance away from human settlement, and index of greenness. Old bitumen exploratory wells, soil, geology, elevation and distance from the ocean with $\operatorname{Exp}(\beta)$ values above 1 are therefore regarded as the most important predictor variables for land degradation. Substituting the coefficients and covariates for (ii), the logistic probability function for the model is written as:

$$
\begin{aligned}
& \mathrm{P}=1 /[1+\exp (-1 *(-1.024+0.44 \text { (oldwell_)-2.496(road_5m) }+0.002 \text { (Mah_sol) }-0.003 \text { (oilfield) }+0.003 \text { (Geol)- } \\
& \text { 0.179(fls)- 0.046(Drain_p) - 0.014(Drain_l) }+0.026(\text { Elev })+0.021 \text { (Ocean) }-0.058 \text { (BUA) }-0.003 \text { (NDVI86) }
\end{aligned}
$$

\subsection{Simulation of probability surface maps}

Five candidate models were developed from the 12 predictor variables and the ranking of the model according to their suitability is done based on the deviation of their AICc from the minimum AICc (Mazerolle 2004) as indicated on Table 7. The global model incidentally has the least AICc (678.77), the highest complexity (13), and the highest Akaike weight (0.99) and is theoretically taken as the best of the candidate models. The global model (model with rank 1) was used to simulate probability surface for the initial (2001) year (Fig 3b) for comparison with the real LULC map (Fig 3a) derived from Landsat imagery. The function was modified to simulate probability maps for future dates by holding the values of all coefficients and covariates constant while varying the value of the intercept in the equation using:

$$
\mathrm{I}_{\mathrm{n}}=\mathrm{I}_{2001} / \mathrm{n}
$$

Where $I_{n}=$ intercept in year $\mathrm{n}, I_{2001}=$ intercept in 2001 and $\mathrm{n}=$ no of years

Figures 3c-f show the simulated probability maps for years 2021, 2031, 2051 and 2101 respectively.

A visual comparison of the true map and the simulated map shows that the model simulates well in most parts of the study area. For example, the degraded areas running east-west along the coastline from the mouth of the Benin River to the boundary of Ogun State was well captured by the model up to Aiyetoro area. The different landcover types, especially heavy forest and palm swamp, cultivation and built up areas were also well simulated. 
The river network and water in over $65 \%$ of the area was also well captured. However, the model appears to have some problems in a localized area around the Benin River estuary where it was unable to simulate the estuary and some other small rivers forming a network west of the Benin River. This may probably have been the result of the wide spatial resolution disparity in some of the data sets and the incomplete geological data coverage. The original geological data did not cover that small part of the study area and was therefore extrapolated.

The simulated probabilities range from 0.4184 to 0.4871 for year 2021, 0.4225 to 4913 for 2031, 0.4259 to 4948 for 2051, and 0.4284 to 0.4973 for 2101 . Attempt was also made to estimate the percent of total landcover that are likely to be affected by future degradation under each probability. For the year 2021, there is between 0.4203 and 0.4335 simulated probabilities that about $87 \%$ of the land will be degraded by 2021 , between 0.4242 and 0.4376 for about $85 \%$ in 2031 , between 0.4278 and 0.4411 for $87 \%$ in 2051 , and between 0.4303 and 0.4436 for $88 \%$ in 2101. In addition, at individual class level, the average probabilities of becoming degraded between 2021 and 2101 range from 0.4257 and 0.4926 for mangrove, to 0.4323 and 0.4874 for lake/pond, 0.4323 and 0.4724 for marshland, 0.4238 and 0.4926 for built-up areas, 0.4390 and 4874 for scrub/grassland, 0.4257 and 0.4720 for light forest/thicket, 0.4257 and 0.4874 for both farmland/fallow and heavy forest, and 0.4257 and 0.4456 for palm swamp. These probabilities suggest the fragile and stressed ecologies including mangrove, marsh, lake/pond, scrub/grassland, farmland/fallow, forest, and thicket have higher probabilities of transiting into degraded lands in future.

\subsection{Implications for natural resource management}

The impacts of increasing ecosystems degradation on the livelihood and well-being of rural population inhabiting the mud beach coast include saline water intrusion into freshwater and land surface leading to decimation of delicate ecosystems, permanent inundation of lands, inundation and siltation of ponds, small lakes and lagoons, inability to use the land for productive purposes, dislocation of the local economy, loss of livelihoods and occupational shifts, uprooting of settlements and forced (environmental) migration with concomitant social and psychological stress from loss of ancestral homelands, loss of biodiversity, etc (Fasona and Omojola, 2009). The coefficients generated by the model are also significant enough to command attention as regards natural resource management and integrated resource planning. Mangrove, scrub/grassland and farmland/fallow ecosystems and built-up areas also appear to have higher simulated probabilities of being degraded in future. This portends serious implications in the future for these delicate ecosystems (which are already seriously decimated) and the habitation and livelihoods of the rural population. This also suggests that more communities may need to relocate in the near future, while the productive lands (upland) that currently support their livelihood may possibly be impacted. The palm swamp ecosystems have the least simulated probabilities of being degraded. This does not suggest that they are not under serious threat. This could be explained by the difficult and inaccessible terrain around them. The high simulated probability for built-up area is also very disturbing. Evidences of abandonment of rural settlements due submergence and saline water inundation, coastal erosion, and disappearance of sources of livelihoods abound. If this trend continues, more presently inhabited rural settlements may be abandoned for new locations in future.

In this study, only 6 of the 12 predictor variables used (old bitumen exploratory wells, road, oilfield, flow-station, drainage line canal, and built-up area) are directly related to human activities while the remaining are the site characteristics of the study area. The influence of underlying forces including economic and political policies that can trigger rapid and spontaneous ecosystems perturbation through large scale on-shore mineral exploration, massive logging, ecosystems destruction for large scale agriculture, and generally, widespread human modification of the environment was not included in the model. Therefore, if we assume that the current rate of transformation of good lands into degraded lands and natural resource depletion will be sustained, the mud beach coast will fare worse in future scenario.

Although the scenario presented in this work is yet to be validated due to inadequate baseline data which throw up the issue of uncertainty, it is presented, therefore, to elicit awareness and discussion support by all stakeholders - governments, oil industry operators, communities, and civil society organizations - for environmental management in the mud-beach coast. Scenarios such as this has been used for climate impact assessment on aspects of socio-ecological systems including water resources, coastal zones, agriculture, human health, forestry, energy, livestock and grasslands, fisheries, forestry, wildlife and biodiversity (Tol, 1998; Smith and Hulme, 1998). In areas (such as the mud beach coast) where livelihoods thrive on natural resource capita, environmental management dictates sustainability of livelihoods (UNEP-UNDP, 2009). A degraded environment increases people's vulnerability to environmental shocks. Improving the ways in which environmental resources 
are managed and mainstreaming livelihood-environment linkages into planning will increase the resilience of poor rural communities to environmental shocks and risks.

\section{Conclusions}

Human induced land degradation poses serious threat to the environment, the natural resource stock and the livelihoods they support in the mud beach coast. The area has experienced ecosystems degradation which has impacted rural livelihoods and homelands (Fasona and Omojola, 2009). However, an integrated picture of the social, economic and ecological impacts has not emerged. Critical data required towards formulating an integrated natural resource and environmental management plan to ensure environmental sustainability is also not available. For a coastal environment with large deposits of hydrocarbon and footprints of accelerated degradation from mineral exploitation, this lack of information is a recipe for ecological disaster. This study is an exploratory attempt to investigate the problem and provide some baseline data for future in-depth studies. It utilizes remote sensing, geographic information systems and spatial statistical model to diagnose the present state of ecosystems and project probabilities of transition of healthy ecosystems into degraded lands in future scenarios.

We have shown in this study that over 30\% of the land has been severely degraded in less than four decades with no artificial restoration taking place. There is over $40 \%$ chance that more ecosystems will be degraded in future scenarios. We have also shown that the location of old bitumen exploratory wells, soil, geology, elevation and distance from the ocean are the prime proximate drivers of ecosystems degradation. This is plausible due to the possibility of a strong association between soil, geology, elevation and distance to the ocean in the mud beach coast. The location of old bitumen well used as proxy for real or present oil wells will, however, create an underestimation of the contribution of oil well location (and all activities that go with it) as a predictor variable. These bitumen wells were captured from geological map prepared at the onset of oil prospecting in the early 1960s. Since then exploration activity has been intensified with many wells now drilled in the on-shore swamps and mangroves. Unfortunately, most of the spatial data on these are not available in the public domain. Hence this study is limited to what was derived from satellite imageries and base maps. This suggests that the magnitude of direct contribution from oil activity to present and probable future degradation of ecosystems in the mud beach coast may be far greater than estimated in this study.

The social and economic impacts of ecosystems degradation and the extent of biodiversity losses are yet to be fully assessed. Field-scale investigations of biodiversity losses, social implications and adjustments, as well as economic evaluation of natural resource and biodiversity losses should be the thrust of future research in the mud beach coast. The influence of future climate change was also not included in the analysis. The mud beach coast is a low-lying area that is highly vulnerable to a possible rise in sea level due to climate change. Climate change may thus constitute an added stress to already threatened ecosystems (UNFCCC, 2007). Future research should also focus on the contribution of climate to the current situation to see how the future scenario will evolve by including climate change as one of the drivers of change. In addition, the underlying drivers of change including globalization, government policies and demographic changes constitute very strong influence for explaining the rate and pattern of transformation of good lands into degraded lands in the mud beach coast that should be fully investigated.

Finally, perhaps there are very few places in Nigeria where the impact of poor environmental management on rural lives and livelihoods is as graphic as in the mud beach coast (Iyun, 1998). Unfortunately, for about forty years the rural dwellers of this coastal countryside have suffered from damage to the environment that they have made no direct contribution. This warrants serious attention from all stakeholders. Public awareness to generate local community support for protection of coastal and marine ecosystems is critical. Options include protection and conservation of mangroves, marsh, sea grass and littoral vegetation. Integrated coastal zone management strategies including better coastal planning and zoning, enforcement of existing legislations against unsustainable resource exploitation and ecosystems management, as well as sustained research into monitoring of the coasts and coastal ecosystems are important. Direct provisions to protect the mud-beach coast environment should also include creation of protected areas and establishing a monitoring system for ecosystems change. The expected take-off of large scale bitumen exploration in the northern axis of the mud beach coast will possibly put more pressure on the ecosystem and the good and services it delivers, which in comparable terms may rival land degradation presently being experienced in the southern axis. A holistic plan which integrates sustainable ecosystems management into resource exploitation plans in the mud beach coast is necessary to ensure environmental sustainability. 


\section{References}

Abiodun, B. J., Pal, J. S., Afiesimama, E. A., Gutowski, W. J., \& Adedoyin, A. (2008). Simulation of West African monsoon using RegCM3 Part II: impacts of deforestation and desertification. Theoretical and Applied Climatology. 93, 245-261. doi:10.1007/s00704-007-0333-1, http://dx.doi.org/10.1007/s00704-007-0333-1

Akegbejo-Samsons, Y. (2008). Impact of Urban Agriculture on Water Reuse and Related Activities on the Rural Population of the Coastal Settlements of Ondo State, Nigeria. African Journal of Food Agriculture Nutrition and Development, 8(1), 48-62.

Anderson, J. R., Hardy, E. E., Roach, J. T., \& Witmer, R. E. (1976). A Land use and Land cover Classification System for use with Remote Sensor Data. Geological Survey Professional Paper, 964, Washington D.C: USGS.

Bedrick, E. J., \& Tsai, C. L. (1994). Model Selection for Multivariate Regression in Small Samples. Biometrics 50 (1), 226-231. doi:10.2307/2533213, http://dx.doi.org/10.2307/2533213

Berger, T., Goodchild, M., Janssen, M. A., Manson, S. M., Najlis, R., \& Parker, D. C. (2001). Methodological considerations for agent-based modeling of landuse and landcover change. In D.C Parker., T. Berger., S. M Manson. (Ed), Agent-Based Models of Landuse and Landcover Change, Report and Review of an International Workshop, LUCC Report Series, 6, www.globallandproject.org Accessed 01 June 2009.

Braimoh, A.K., \& Onishi, T. (2006). Spatial Determinants of urban landuse change in Lagos, Nigeria. Landuse Policy.

Burnham, K. P., \& Anderson, D. R. (1998). Model Selection and Inference: A Practical Information-Theoretic Approach. Berlin: Springer-Verlag.

Cavanaugh, J. E. (1997). Unifying the derivations for Akaike and corrected Akaike information Criteria. Statistics and Probability Letters 0167-7152, 33, 201-208.

Curran, P. J \& Atkinson, P. M (1998). Geostatistics and remote sensing. Progress in Physical Geography, 22 (1), 61-78.

Dale, M.R.T \& Fortin, M.J. (2002). Spatial autocorrelation and statistical tests in ecology. Ecoscience, 9(2) 162-167.

Dormany, G. (2000). Forest Fire in the Velence Mountains. ACTA Geographica Szegediensis Tomus XXXVII, 19-28.

Eastman, J. R (2009): Idrisi Taiga Guide to Image Processing, Clark Labs. Clark University, Worcester, MA.

Fang, S., Gertnera, G. Z, Sun, Z., \& Anderson, A. A (2005). The impact of interactions in spatial simulation of the dynamics of urban sprawl. Landscape and Urban Planning, 73, 294-306. doi:10.1016/j.landurbplan.2004.08.006, http://dx.doi.org/10.1016/j.landurbplan.2004.08.006

Fasona, M., \& Omojola, A. (2009). Land cover change and land degradation in parts of the southwest coast of Nigeria. African Journal of Ecology, 47(S1), 30-38. doi:10.1111/j.1365-2028.2008.01047.x, http://dx.doi.org/10.1111/j.1365-2028.2008.01047.x

Fasona, M., Omojola, A., \& Onyeahialam, A. (2007). Mapping land degradation and forest resource loss from fused Landsat TM and Nigeriasat-1 images in some parts of the southwest coast of Nigeria. In M. Owe., C. Neale. (Ed), Remote Sensing for Environmental Monitoring and Change Detection, IAHS Publ. 316, $110-118$.

Fasona, M. J. (2007). Land degradation and environmental change in Ondo State coastline, southwest Nigeria. PhD Thesis, University of Lagos. Lagos, 238p

Feddema, J. J., \& Freire, S. (2001). Soil degradation, global warming and climate impacts. Climate Research, 17, 209-216. doi:10.3354/cr017209, http://dx.doi.org/10.3354/cr017209

Feng, Y., Lu, Q., Tokola, T., Liu, H., \& Wang, X. (2009). Assessment of grassland degradation in Guinan County, Qinghai province, China, in the past 30 years. Land Degradation and Development, 20, 55-68. doi:10.1002/ldr.877, http://dx.doi.org/10.1002/ldr.877

Folke, C., Pritchard Jr, L., Berkes, F. Colding, J., \& Svedin, U. (1998). IHDP working paper 02, www.ihdp.uni-bonn.de/html/publications/workingpaper/wp02m. Accessed 08 September 2009.

Fuller, D. O., \& Ottke, C. (2002). Land cover, rainfall and land-surface albedo in West Africa. Climatic Change, 54, 181-204. doi:10.1023/A:1015730900622, http://dx.doi.org/10.1023/A:1015730900622 
Geist, H. J., \& Lambin, E. F. (2002). Proximate Causes and Underlying driving forces of tropical deforestation. Bioscience, $52 \quad$ (2), 143-150. doi:10.1641/0006-3568(2002)052[0143:PCAUDF]2.0.CO;2, http://dx.doi.org/10.1641/0006-3568(2002)052[0143:PCAUDF]2.0.CO;2

German Advisory Council on Climate Change. (2008). Climate change as a security risk. London: Earthscan.

German Advisory Council on Global Change. (2000). World in Transition: Strategies for Managing Global Environmental Risks. Berlin: Springer-Verlag.

Gobin, A., Campling P., \& Feyen J. (2002): Logistic modelling to derive agricultural land use determinants: a case study from south-eastern Nigeria. Agriculture, Ecosystems and Environment, 89, 213-228. doi:10.1016/S0167-8809(01)00163-3, http://dx.doi.org/10.1016/S0167-8809(01)00163-3

Griffith, D (1987). Spatial Autocorrelation: A Primer. Resource Publications in Geography, Association of American Geographers.

Hagget, P., \& Chorley, R. J. (1967) Models, Paradigms and the new Geography. In R.J Chorley., P. Hagget (Ed), Models in Geography, (pp19-41). London: Methuen \& Co Ltd.

Hall, C. A. S., Tian, H., Qi, Y., Pontius, G., \& Cornell, J. (1995). Modelling Spatial and Temporal Patterns of Tropical Land Use Change. Journal of Biogeography, 22, 4/5, Terrestrial Ecosystem Interactions with Global Change, 2, 753-757.

Hoffmann, W. A., \& Jackson, R. B. (2000). Vegetation-Climate Feedbacks in the Conversion of Tropical Savanna to Grassland. Journal of Climate, 13, 1593-1602. doi:10.1175/1520-0442(2000)013<1593:VCFITC $>2.0 . C O ; 2$, http://dx.doi.org/10.1175/1520-0442(2000)013<1593:VCFITC $>2.0 . C O ; 2$

Iyun, B. F. (1998). Women status, environmental changes and child health in riverine area of Ondo state, Nigeria. Geojournal, 44(2), 129-139. doi:10.1023/A:1006836103154, http://dx.doi.org/10.1023/A:1006836103154

Iyun, B. F., \& Oke, E. A. (2000) Ecological and cultural barriers to treatment of childhood diarrhea in riverine areas of Ondo State, Nigeria. Social Science \& Medicine, 50, 953-964. doi:10.1016/S0277-9536(99)00347-0, http://dx.doi.org/10.1016/S0277-9536(99)00347-0

Jensen, J. R. (1986). Introductory Digital Image Processing-a remote sensing perspective. New Jersey: Prentice-Hall,

Jones, H. A., \& Hockey, R. D. (1964). The geology of part of S.W Nigeria, explanation of 1:250,000 Sheets Nos 59 and 68. Geological Survey of Nigeria Bulletin, 31, 101p.

Kok, K., Veldkamp, A. (2001). Evaluating impact of spatial scales on land use pattern analysis in Central America. Agriculture, Ecosystems and Environment, 85, 205-221. doi:10.1016/S0167-8809(01)00185-2, http://dx.doi.org/10.1016/S0167-8809(01)00185-2

Kottek, M., Grieser, J., Beck, C., Rudolf, B., \& Ru, F. (2006). World map of the Köppen-Geiger climate classification updated. Meteorologische Zeitschrift, 15(3), 259-263. doi:10.1127/0941-2948/2006/0130, http://dx.doi.org/10.1127/0941-2948/2006/0130

Lambin, E. F. (1997). Modelling and monitoring landcover change processes in tropical regions. Progress in Physical Geography, 21(3), 375-393. doi:10.1177/030913339702100303, http://dx.doi.org/10.1177/030913339702100303

Lebel, L., \& Steffen, W. (1998). Global Environmental Change and Sustainable Development: Science Plan for a SARCS Integrated Study. Science Plan Southeast Asian Regional Development Committee for START (SARCS), 139p.

MacKellar, N. C., Tadross, M. A, \& Hewitson, B. C (2009). Effects of vegetation map change in MM5 simulations of Southern Africa's summer climate. International Journal of Climatology, 29, 885-898. doi:10.1002/joc.1754, http://dx.doi.org/10.1002/joc.1754

Mazerolle, M. J. (2004). Making Sense out of Akaike's Information Criterion (AIC): Its use and interpretation in model selection and inference from ecological data www.theses.ulaval.ca/2004/21842/apa.html, retrieved 20 June 2007.

Millennium Ecosystems Assessment. (2005). Ecosystems and Human Well-being: Framework for Assessment: http://www.maweb.org/documents/document.299.aspx.pdf. Accessed 23 October 2009.

Mitchell, B. (1989). Geography and Resource Analysis, London: Longman Group. 
Mitchell, R. E. (2001). Predictability of Hunting: A Logistic Regression Analysis of Western Canadian Hunters. Crossing Boundaries - an interdisciplinary journal, 1(1), 107-117.

NASA Landsat Program, 2003, Landsat ETM+ scene p190r056, Orthorectified, USGS, Sioux Falls, 2001-02-17. Source for this dataset was the Global Land Cover Facility, www.landcover.org, retrieved 02 May 2005.

Ojima, D. S., Galvin, K. A. \& Turner II, B. L. (1994). The global impact of land use change. Bioscience, 44(5). doi:10.2307/1312379, http://dx.doi.org/10.2307/1312379

Overmars, K. P., de Koning, G. H. J., \& Veldkamp, A. (2003). Spatial autocorrelation in multi-scale land use models. Ecological Modelling, 164 (2003) 257-270. doi:10.1016/S0304-3800(03)00070-X, http://dx.doi.org/10.1016/S0304-3800(03)00070-X

Pontius Jr, G. R., \& Malanson, J. (2005). Comparison of the structure and accuracy of two land change models. International Journal of Geographical Information Science, 19(2), 243-265. doi:10.1080/13658810410001713434, http://dx.doi.org/10.1080/13658810410001713434

Pontius Jr, R. G., \& Schneider, L. C. (2001). Land-cover change model validation by an ROC method for the Ipswich watershed, Massachusetts, USA. Agriculture, Ecosystems and Environment, 85, 239-248. doi:10.1016/S0167-8809(01)00187-6, http://dx.doi.org/10.1016/S0167-8809(01)00187-6

Population Reference Bureau. (2001). Healthy People Need Healthy Forests - Population and Deforestation, PRB, October 2001.

Reynolds, J. F., Stafford, S., \& Lambin, E. (2003). ARIDnet: Seeking novel approaches to desertification and land degradation. Global Change newsletter, 54, 5-9.

Riebsame, W. E., Parton, K. A., Havin, I. C., Burke, L., Bohren, R. Y., \& Knop, E. (1994). Integrated modeling of Land use and cover change. Bioscience, 44(5). doi:10.2307/1312385, http://dx.doi.org/10.2307/1312385

Smith, J. B., \& Hulme, M. (1998). Climate Change Scenarios. In F. Jan., J. F Feenstra., I Burton., J. B Smith., R. S. J Tol. (Ed), Handbook on Methods for Climate Change Impact Assessment and Adaptation Strategies, Version 2.0, UNEP/IVM Handbook.

Solomon S., Qin D., Manning M., Alley R. B., Berntsen T., Bindoff N. L., Chen Z., Chidthaisong A., Gregory J. M., Hegerl G. C., Heimann M., Hewitson B., Hoskins B. J., Joos F., Jouzel J., Kattsov V., Lohmann U., Matsuno T., Molina M., Nicholls N., Overpeck J., Raga G., Ramaswamy V., Ren J., Rusticucci M, Somerville R., Stocker T. F., Whetton P., Wood R. A., \& Wratt D. (2007). Technical Summary. In S Solomon., D Quin., M Manning., Z Chen., M Marquis., K. B Averyt., M Tignor, H. L Miller. (Ed), Climate Change 2007: The Physical Science Basis. Contribution of Working Group I to the Fourth Assessment Report of the Intergovernmental Panel on Climate Change. Cambridge and New York: Cambridge University Press.

Stéphenne, N., \& Lambin, E. F (2001). A dynamic simulation model of landuse changes in Sudano-sahelian countries of Africa. Agriculture, Ecosystems and Environment, 85, 145-161. doi:10.1016/S0167-8809(01)00181-5, http://dx.doi.org/10.1016/S0167-8809(01)00181-5

Taylor, C. M., Lambin, E. F., Stephenne, N., Harding, R. J., \& Essery, R. L. (2002). The Influence of Land Use Change on Climate in the Sahel. Journal of Climate, 15, 3615-3629. doi:10.1175/1520-0442(2002)015<3615:TIOLUC $>2.0$. CO;2, http://dx.doi.org/10.1175/1520-0442(2002)015<3615:TIOLUC $>2.0 . C O ; 2$

Tol, R. S. J. (1998). Socio-economic Scenarios. In F. Jan., J.F Feenstra., I Burton., J. B Smith., R. S. J Tol. (Ed), Handbook on Methods for Climate Change Impact Assessment and Adaptation Strategies, Version 2.0, UNEP/IVM Handbook.

UNDP-UNEP. (2009). Mainstreaming Poverty-Environment Linkages into Development Planning: A Handbook for Practitioners. Accessed 23 July 2010. Available online at www.unpei.org

UNEP/GRID-Arendal. (2005). Environment Times, 3, GRID-Arendal, Logum Park, Service Box 706, Arendal.

United Nations Framework Convention on Climate Change (2007). Climate Change: Impacts, Vulnerabilities and Adaptation in Developing Countries. UNFCCC: Bonn

Veldkamp, A., \& Fresco, L. O. (1996). CLUE: A conceptual model to study the Conversion of Land Use and its Effects. Ecological Modelling, 85, 253-270. doi:10.1016/0304-3800(94)00151-0, http://dx.doi.org/10.1016/0304-3800(94)00151-0 
Veldkamp, A., \& Lambin, E. F. (2001). Predicting landuse change. Agriculture, Ecosystems and Environment, 85, 1-6. doi:10.1016/S0167-8809(01)00199-2, http://dx.doi.org/10.1016/S0167-8809(01)00199-2

Veldkamp, A., \& Verburg, P. H. (2004). Editorial: Modelling land use change and environmental impact. Journal of Environmental Management, 72, 1-3. doi:10.1016/j.jenvman.2004.04.004, http://dx.doi.org/10.1016/j.jenvman.2004.04.004

Verburg, P. H., Chen, Y., Soepboer, W., \& Veldkamp, T. A. (2000). GIS-based modeling of human-environment interactions for natural resource management applications in Asia. Proceedings of the 4th International Conference on integrating GIS and Environmental Modelling: Problems, Prospect and Research Needs, Banff, Alberta, Canada.

Verburg, P. H., Veldkamp, A., Espaldon, R. L., \& Mastura, S. S. (2002). Modeling the spatial dynamics of regional land use: the CLUE-S Model. Environmental Management, 30(3), 301-405. doi:10.1007/s00267-002-2630-x, http://dx.doi.org/10.1007/s00267-002-2630-x

Verstappen, H. T. (1999). Environmental Hazards and the Use of Satellite Remote sensing for Sustainable Development. In P.O Adeniyi (Ed) Geoinformation Technology Applications for Resource and Environmental Management in Africa (pp57-64), Lagos: AARSE.

Wang, G. L., \& Eltahir, E. A. (2000). Biosphere-atmosphere interactions over West Africa. II: Multiple climate equilibria. Quaternary Journal of the Royal Meteorological Society, 126, 1261-1280. doi:10.1256/smsqj.56503, http://dx.doi.org/10.1256/smsqj.56503

Warren, A. (2002). Land degradation is Contextual. Land Degradation and Development, 13, 449-459. doi:10.1002/ldr.532, http://dx.doi.org/10.1002/ldr.532

Wheeler, D. J. (1994). Linking Environmental Models with GIS for Global Research. In W.J Ripple (Ed), GIS Application book examples in Natural Resources: A Compendium, American Society for Photogrammetry and Remote Sensing.

Wright, J. B., Hastings, D. A., Jones, W. B., \& William, H. R. (1985). Geology and Mineral Resources of West Africa, London: George Allen and Unwin.

Zurayk, R., El-Awar, F., Hamadeha, S., Talhouk, S., Sayegh, C., Chehab, A., \& Al-Shab, K. (2001). Using indigenous knowledge in land use investigations: A participatory study in a semi-arid mountainous region of Lebanon. Agriculture, Ecosystems and Environment, 86, 247-262. doi:10.1016/S0167-8809(00)00287-5, http://dx.doi.org/10.1016/S0167-8809(00)00287-5 
Table 1. Data types and sources

\begin{tabular}{|c|c|c|c|c|c|}
\hline Data & $\begin{array}{c}\text { Identification and } \\
\text { Coverage }\end{array}$ & Scale/resolution & Date & Source(s) & $\begin{array}{l}\text { Candidate } \\
\text { predictor } \\
\text { variable } \\
\text { generated }\end{array}$ \\
\hline $\begin{array}{l}\text { Landsat } \mathrm{ETM}^{+} \\
\text {imagery from } \\
\text { Landsat } 7\end{array}$ & Path 190 ROW 056 & $\begin{array}{c}\text { Spatial resolution - } \\
\text { P-15m } \\
\text { B-IR } 30 \mathrm{~m} \times 30 \mathrm{~m} \\
\text { TIR-60m } \\
\text { Spectral resolution - } \\
\text { 8bands }\end{array}$ & $17 / 02 / 2001$ & $\begin{array}{l}\text { NASA Landsat Program, } \\
2003 . \\
\text { http://www.landcover.org/ }\end{array}$ & $\begin{array}{c}\text { Original } \\
\text { vector } \\
\text { landcover data }\end{array}$ \\
\hline $\begin{array}{l}\text { Topographic } \\
\text { Maps }\end{array}$ & \begin{tabular}{|} 
Mahin $296 \mathrm{NW}$, \\
NE, SW, SE; \\
Okomu 297SW, \\
Molume 307NE and \\
Benin River \\
308NW
\end{tabular} & $1: 50,000$ & $\begin{array}{c}\text { Air } \\
\text { Photography } \\
\text { of Nov/Dec } \\
1965\end{array}$ & $\begin{array}{l}\text { Federal Surveys } \\
\text { Department }\end{array}$ & $\begin{array}{l}\text { Elevation } \\
(\text { ELEV) }\end{array}$ \\
\hline Geology map & Okitipupa Sheet 69 & $1: 250,000$ & 1962 & $\begin{array}{c}\text { Nigeria Geological } \\
\text { Surveys }\end{array}$ & $\begin{array}{l}\text { Geology types } \\
\text { (GEOL), } \\
\text { distance to old } \\
\text { bitumen wells } \\
\text { (OLDWELL) }\end{array}$ \\
\hline Soils map & $\begin{array}{c}\text { Soils map of } \\
\text { Nigeria, sheet } 7\end{array}$ & $1: 650,000$ & 1990 & $\begin{array}{l}\text { Soils Survey Division, } \\
\text { Min of Agric and } \\
\text { Natural Resources }\end{array}$ & $\begin{array}{c}\text { Soil types } \\
\left(\mathrm{MAH} \_\mathrm{SOL}\right)\end{array}$ \\
\hline $\begin{array}{c}\text { Oil } \\
\text { Infrastructure } \\
\text { Map }\end{array}$ & $\begin{array}{l}\text { Major settlement } \\
\text { and oil } \\
\text { infrastructures }\end{array}$ & $1: 250,00$ & 1997 & $\begin{array}{c}\text { Department for Petroleum } \\
\text { Resources }\end{array}$ & \begin{tabular}{|} 
Distance to oil \\
field \\
(OILFIELD), \\
distance to \\
flow stations \\
(FLS),
\end{tabular} \\
\hline $\begin{array}{c}\text { Administrative } \\
\text { maps }\end{array}$ & $\begin{array}{c}\text { Harmonized admin } \\
\text { boundary map for } \\
\text { Nigeria }\end{array}$ & $1: 250,000$ & 1997 & $\begin{array}{c}\text { Laboratory for } \\
\text { Cartography and Remote } \\
\text { Sensing (LABCARS) } \\
\text { UNILAG }\end{array}$ & \\
\hline
\end{tabular}


Table 2. Selected candidate predictor variables and weights

\begin{tabular}{|l|l|l|l|}
\hline $\mathrm{S} / \mathrm{n}$ & Variables & Rank (1 being highest) & Weight \\
\hline 1 & Elevation & 1 & 12 \\
\hline 2 & Geology & 2 & 11 \\
\hline 3 & Soil & 3 & 10 \\
\hline 4 & NDVI- index of greenness & 4 & 9 \\
\hline 5 & Distance from ocean & 5 & 8 \\
\hline 6 & Distance from known oil field & 6 & 7 \\
\hline 7 & Distance from drainage & 7 & 6 \\
\hline 8 & Distance from human settlement & 8 & 5 \\
\hline 9 & Distance from old oil/bitumen well & 9 & 4 \\
\hline 10 & Distance from dredged canal & 10 & 3 \\
\hline 11 & Distance from known flow-station & 11 & 2 \\
\hline 12 & Distance from road & 12 & 1 \\
\hline
\end{tabular}

Table 3. Spatial autocorrelation in predictors

\begin{tabular}{|l|l|l|l|l|l|}
\hline $\mathrm{Sn}$ & Factor & Moran I & Expected I & Variance & Z score \\
\hline 1 & OLDWELL_(distance from old bitumen wells) & $0.107794^{* *}$ & -0.001189 & 0.000016 & 27.261158 \\
\hline 2 & ROAD_5M (distance from road) & $0.018638^{* *}$ & -0.001189 & 0.000011 & 6.051668 \\
\hline 3 & MAH_SOL (soil type) & $0.248678^{* *}$ & -0.001189 & 0.000017 & 60.36215 \\
\hline 4 & OILFIELD (distance from oil field) & $0.136581^{* *}$ & -0.001189 & 0.000017 & 33.6721 \\
\hline 5 & GEOL (geology type) & $0.043645^{* *}$ & -0.001189 & 0.000017 & 10.756955 \\
\hline 6 & FLS (distance from oil flow-stations) & $0.025147^{*}$ & -0.001189 & 0.000003 & 16.638525 \\
\hline 7 & DRAIN_P (distance from drainage) & $0.05697^{* *}$ & -0.001189 & 0.000017 & 13.971621 \\
\hline 8 & DRAIN_LI (distance from dredge canals) & $0.037362^{* *}$ & -0.001189 & 0.000017 & 9.294388 \\
\hline 9 & ELEV (elevation) & $0.346921^{* *}$ & -0.001189 & 0.000017 & 83.320661 \\
\hline 10 & OCEAN (distance from the ocean) & $0.255014^{* *}$ & -0.001189 & 0.000017 & 61.438491 \\
\hline 11 & BUA (distance from human habitation/settlement) & $0.00819^{* *}$ & -0.001189 & 0.000017 & 2.289918 \\
\hline 12 & NDVI86 (Index of greenness) & $0.025126^{* *}$ & -0.001189 & 0.000017 & 6.308155 \\
\hline
\end{tabular}

* Significant $(\mathrm{p}<0.05) * *$ significant $(\mathrm{p}<0.01)$

Table 4. Coverage of degraded ecologies of the area in percent

\begin{tabular}{|l|l|l|l|l|}
\hline SN & Ecological Class & \multicolumn{4}{l|}{ Percent Landuse/Landcover } \\
\hline & & 2001 & 1986 & 1965 \\
\hline 1 & Dredged River/Canal & 0.4 & 0.6 & - \\
\hline 2 & Permanently inundated lands & 10.0 & 1.2 & - \\
\hline 3 & Burrow Pit/Excavated land & 0.1 & - & - \\
\hline 4 & Bare Surfaces & 12.4 & 1.7 & - \\
\hline 5 & Devegetated Areas & 4.4 & 3.6 & \\
\hline 6 & Scrub/grassland & 2.9 & 3.4 & - \\
\hline 7 & Dredged Spoil & 0.01 & - & - \\
\hline 8 & Mud & 0.01 & - & - \\
\hline & & $\mathbf{3 0 . 2 2}$ & $\mathbf{1 0 . 5 0}$ & \\
\hline
\end{tabular}


Table 5. Summary of recorded land degradation types

\begin{tabular}{|c|c|c|c|c|c|}
\hline $\mathrm{Sn}$ & Degradation & $\begin{array}{l}\text { Extent } \\
\text { in } 2001\end{array}$ & $\begin{array}{l}\text { Annual } \\
\text { growth } \\
\text { rate } \\
(1986-2 \\
001)\end{array}$ & Causes & Effect \\
\hline 1 & $\begin{array}{l}\text { Scrub/coastal } \\
\text { grassland-indicator } \\
\text { of disturbance or } \\
\text { strong perturbations } \\
\text { created by pressure } \\
\text { on existing ecologies }\end{array}$ & $\begin{array}{l}9,544 h \\
a\end{array}$ & $-0.9 \%$ & $\begin{array}{l}\text { Farming, fuel wood } \\
\text { harvesting, logging and } \\
\text { bush clearing and } \\
\text { burning activities }\end{array}$ & $\begin{array}{l}\text { Reduction in soil nutrient loss of } \\
\text { resilience and stability, forest loss }\end{array}$ \\
\hline 2 & Submerged area & $\begin{array}{l}32,969 \\
\text { ha }\end{array}$ & $4.9 \%$ & $\begin{array}{l}\text { saline water inflow into } \\
\text { freshwater and the land } \\
\text { areas }\end{array}$ & $\begin{array}{l}\text { massive loss of marsh and } \\
\text { mangrove, decimation of more } \\
\text { habitats, forced relocation of } \\
\text { settlements, inundation of small } \\
\text { lakes and ponds, loss of livelihood, } \\
\text { loss of fauna and flora. }\end{array}$ \\
\hline 3 & Dredged canal & 9 nos & $-1.7 \% *$ & Oil activities & $\begin{array}{l}\text { opening of the land area to } \\
\text { inundation from sea water }\end{array}$ \\
\hline 4 & Bare surfaces & $\begin{array}{l}\text { 41,062 } \\
\text { ha }\end{array}$ & $0.4 \%$ & $\begin{array}{l}\text { Logging, agriculture, } \\
\text { pressure on existing } \\
\text { ecologies }\end{array}$ & $\begin{array}{l}\text { Decreasing agric productivity, } \\
\text { relocation of some settlements, }\end{array}$ \\
\hline 5 & $\begin{array}{l}\text { Devegetated lands - } \\
\text { high transformation } \\
\text { pressure }\end{array}$ & $\begin{array}{l}14,460 \\
\text { ha }\end{array}$ & $0.6 \%$ & $\begin{array}{l}\text { logging activities, fuel } \\
\text { wood for domestic uses } \\
\text { (firewood), agriculture }\end{array}$ & $\begin{array}{l}\text { Decreasing agric productivity, loss } \\
\text { of forest }\end{array}$ \\
\hline 6 & $\begin{array}{l}\text { Burrow Pit/ } \\
\text { Excavated Lands }\end{array}$ & 246ha & & oil activities & Artificial pits, forest loss, \\
\hline 7 & $\begin{array}{l}\text { Mud and Dredge } \\
\text { Spoil }\end{array}$ & 148ha & & $\begin{array}{l}\text { Natural causes, oil } \\
\text { activity }\end{array}$ & Soil impaction \\
\hline 8 & Coastal erosion & & & $\begin{array}{l}\text { Global and regional } \\
\text { oceanic processes }\end{array}$ & $\begin{array}{l}\text { Beach sand/mud loss, settlement } \\
\text { dislocation }\end{array}$ \\
\hline 9 & $\begin{array}{lr}\text { Inundation } & \text { and } \\
\text { disappearance } & \text { of } \\
\text { lakes and ponds } & \end{array}$ & & $-4.9 \%$ & $\begin{array}{l}\text { Saline water inflow, } \\
\text { lake siltation and } \\
\text { natural shrinkage }\end{array}$ & $\begin{array}{l}\text { Loss of livelihood, economic } \\
\text { losses, increase poverty, settlement } \\
\text { dislocation, loss of flora and fauna } \\
\text { of lake/pond ecosystem, }\end{array}$ \\
\hline
\end{tabular}

*Some of the canal routes in inundated lands were not mappable in 2001 
Table 6. Performance of predictor variables

\begin{tabular}{|c|c|c|c|c|c|}
\hline Sn & Predictor Variables & $\beta$ & S.E. & Sig. & Exp( $\beta)$ \\
\hline 1 & OLDWELL_(distance from old bitumen wells) & .044 & .027 & .096 & 1.045 \\
\hline 2 & ROAD_5M (distance from road) & -2.496 & 7.653 & .744 & .082 \\
\hline 3 & MAH_SOL (soil type) & .002 & .013 & .876 & 1.002 \\
\hline 4 & OILFIELD (distance from oil field) & -.003 & .018 & .848 & .997 \\
\hline 5 & GEOL (geology type) & .003 & .005 & .520 & 1.003 \\
\hline 6 & FLS (distance from oil flow-stations) & -.179 & .599 & .765 & .836 \\
\hline 7 & DRAIN_P (distance from drainage) & -.046 & .013 & .000 & .955 \\
\hline 8 & DRAIN_LI (distance from dredge canals) & -.014 & .010 & .158 & .986 \\
\hline 9 & ELEV (elevation) & .026 & .006 & .000 & 1.027 \\
\hline 10 & OCEAN (distance from the ocean) & .021 & .009 & .018 & 1.021 \\
\hline 11 & BUA (distance from human habitation/settlement) & -.058 & .033 & .079 & .944 \\
\hline 12 & NDVI86 (Index of greenness) & -.003 & .004 & .389 & .997 \\
\hline
\end{tabular}

$\beta=$ Beta, S.E $=$ Standard error of $\beta$, Sig $=$ significance, $\operatorname{Exp}(\beta)=$ exponent (antilog) Beta

Table 7. AIC Performance of the potential models

\begin{tabular}{|c|c|c|c|c|c|c|c|c|c|}
\hline $\begin{array}{l}\text { Model } \\
\text { No }\end{array}$ & Models & $\mathrm{K}+1$ & $-2 \mathrm{LL}$ & $\mathrm{N}$ & AIC & $\mathrm{AICc}$ & $\Delta \mathrm{i}$ & AIC (wi) & Rank \\
\hline 1 & $\begin{array}{c}\text { Oldwell_+ Road_5m+ } \\
\text { Mah_sol+Oilfield+Geol+ } \\
\text { FLS+ Drain_P+ Drain_L+ } \\
\text { Elev+ Ocean+ BUA+NDVI86 }\end{array}$ & 13 & 652.34 & 842 & 678.34 & 678.77 & 0.00 & 0.9999693166 & 1 \\
\hline 2 & $\begin{array}{c}\text { Oldwell_+ Mah_sol+ Geol+ } \\
\text { Elev+ Ocean+ NDVI86 }\end{array}$ & 7 & 685.44 & 842 & 699.44 & 699.57 & 20.80 & 0.0000304669 & 2 \\
\hline 3 & $\begin{array}{c}\text { Oldwell_+ Road_5m+ } \\
\text { Mah_sol+ FLS+ Drain_P+ } \\
\text { Drain_L }\end{array}$ & 7 & 724.52 & 842 & 738.52 & 738.65 & 59.88 & 0.0000000000 & 5 \\
\hline 4 & Elev+ Ocean+ BUA+ NDVI86 & 5 & 717.33 & 842 & 727.33 & 727.40 & 48.63 & 0.0000000000 & 4 \\
\hline 5 & $\begin{array}{c}\text { Oldwell_+ Road_5m+ } \\
\text { Mah_sol+ Oilfield+ Geol+ } \\
\text { FLS+ Drain_P+ Drain_L }\end{array}$ & 9 & 691.25 & 842 & 709.25 & 709.47 & 30.70 & 0.0000002165 & 3 \\
\hline
\end{tabular}

$\mathrm{K}=$ number of parameters

$\mathrm{N}=$ Sample size (i.e. number of polygons)

$-2 \mathrm{LL}=-2 \log$ likelikood

$\mathrm{AIC}=-2 \mathrm{LL}+2 \mathrm{~K}$

$\mathrm{AICc}=[\mathrm{AIC}+(2 \mathrm{~K}(\mathrm{~K}+1)) /(\mathrm{n}-\mathrm{K}-1)]$

$\Delta \mathrm{i}=\mathrm{AICc}(\mathrm{i})-\mathrm{min} A \mathrm{ICc}$ (the difference between the AICc of model $\mathrm{i}$ and the minimum AICc)

$\mathrm{AIC}(\mathrm{wi})=\underline{\exp (-\Delta \mathrm{i} / 2)}$

$\Sigma_{\mathrm{r}}^{\mathrm{R}}=1 \exp (-\Delta \mathrm{r} / 2)$ 


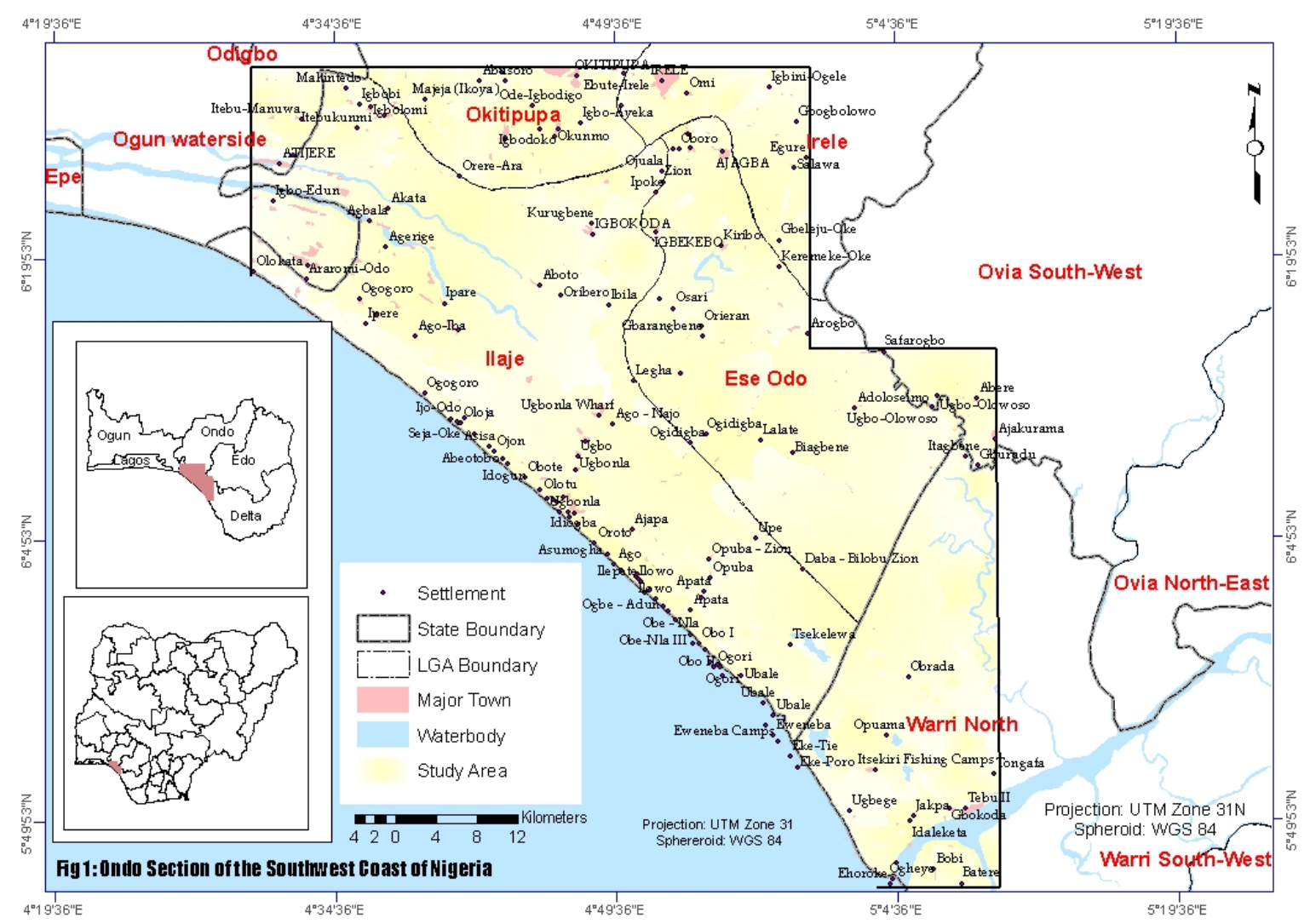

Figure 1. The study area

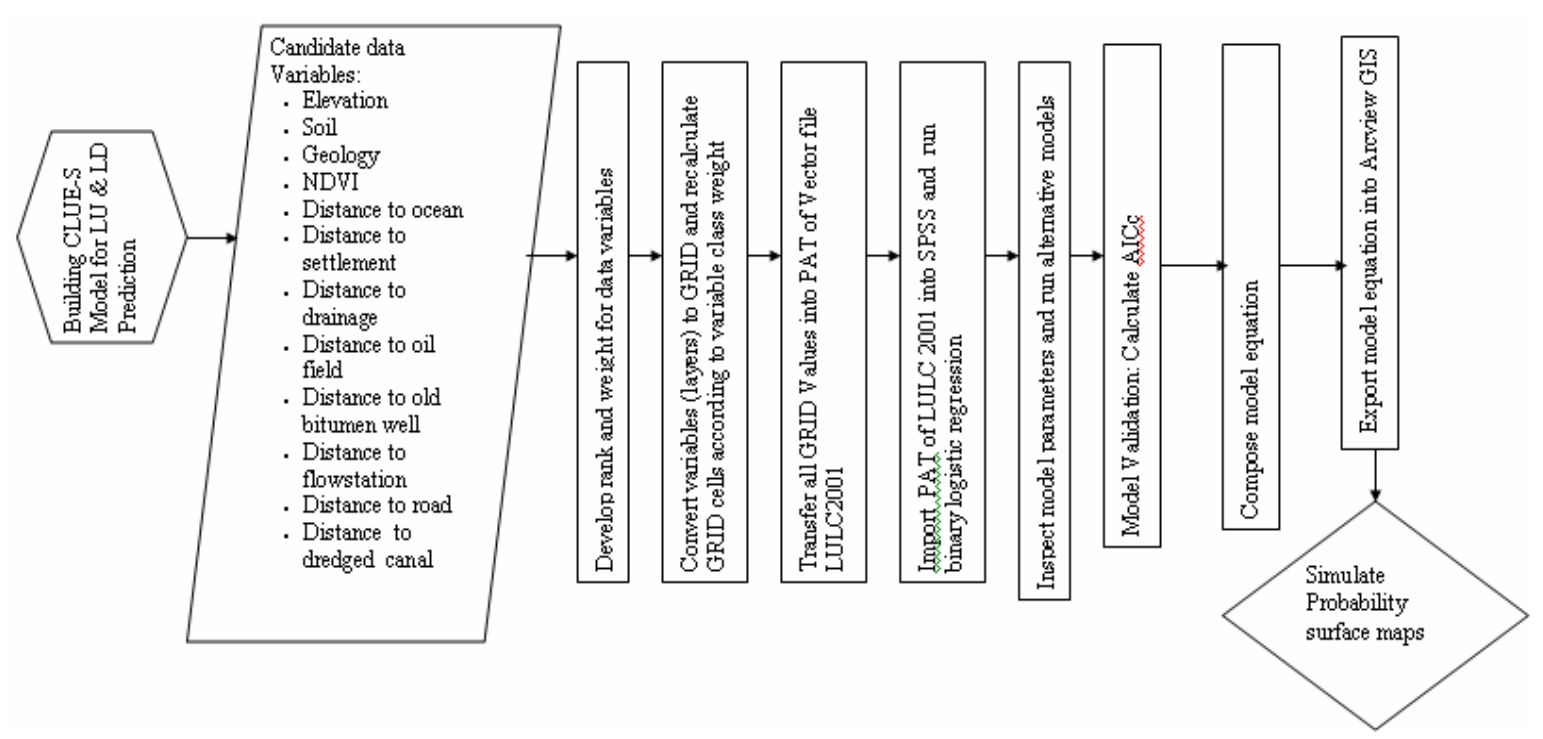

Figure 2. Framework used to develop the probability surface maps 

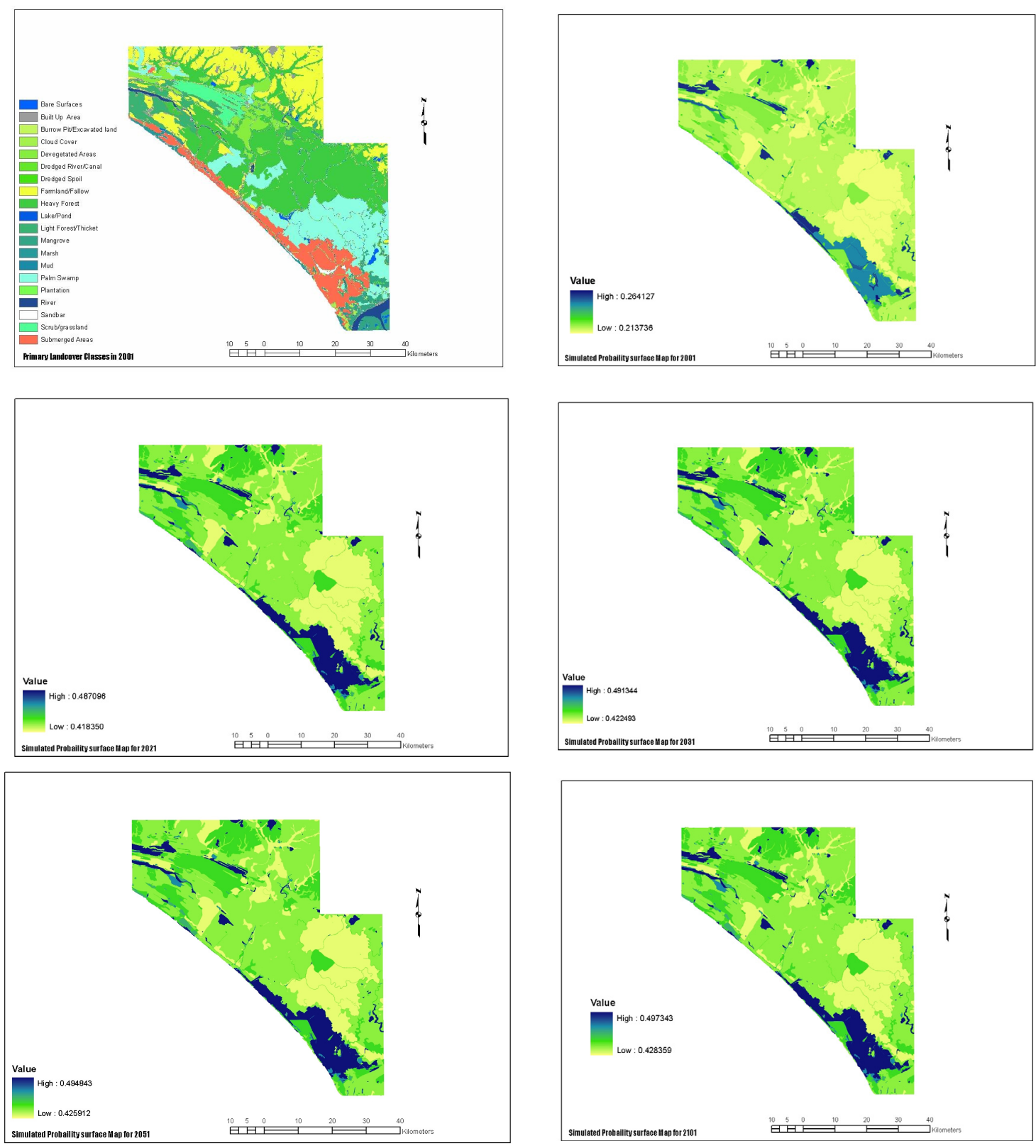

Figure 3a-f. from L-R (a) LULC map derived from Landsat imagery for 2001

(b)-simulated landcover map for 2001 (c) simulated map for 2021

(d) simulated map for 2031 (e) simulated map for 2051 (f) simulated map for 2101 